\title{
Urbanization and Urbanism as a Way of Life: The Case of Konya as a Metropolitan Village in Turkey

\author{
Ass.Prof.Dr. Özgür Sarı
}

Selçuk University

Department of Sociology

Doi:10.5901/ajis.2013.v2n8p260

\section{Abstract}

Cities and urban has being studied not only by architecture, city planning, but also politics, sociology, economics, and geography; therefore, urban studies is an interdisciplinary area that aims to understand the process of urbanization and cities as characteristics of 20th and 21st centuries. Different fields recognize that urbanization is not only physical process occurring on space, but a social and economic process that affects the social behaviors of people. Higher population density and higher buildings are not only indicators of urbanization, but also there are some other indicators of social behavior that show us urbanization. To being urbanized, scholars are expecting some behavior habits and patterns from the living people. Around the theoretical arguments of social phenomenon of urbanization, the case of Konya will be analyzed. While, Konya is being accepted as metropolitan city including service and industrial sectors and population density, living people in Konya is still having traditional patterns regarding to rural. The study will be strengthened with the researches on social patterns of people living in Konya, conducted by the Konya Metropolitan Municipality.

Keywords: Urbanization, Urbanism, Metropolitan Village, Urban, Rural.

\section{Introduction}

$76.8 \%$ of the population is living in urban in Turkey (http://www.tuik.gov.tr/PreHaberBultenleri.do?id=10736), and $18.2 \%$ of the total population is living only in one city, Istanbul. Therefore to understand the Turkish society, we must analyze the urban population and look at the social dynamics of urban deeply. There are many disciplines focusing on urban from Sociology, to Economics, from City Planning to Politics. While, urban is being studied by many disciplines, there are many points of views and theories to explain urban. Such a multi-dimensional phenomenon, urban can be defined through its geographical distinction, such as being larger than rural, through its economic structure, such as being industrial and service sector center, or through political features such as having developed civil society and democratic values.

Sociology starts focusing on urban after the Industrial Revolution within two hundred years, just after the rapid birth and growth of cities including accumulation of industrial production and trade facilities. New social classes, such as working class and urban middle class, were born and new social movements and revolutions occurred in cities. Urban is the most important spatial area where social practices, ideologies, and production relations, and some other social parameters (Tolan, 1991: 60).

This study will focus on urbanization and urbanism through some theoretical perspectives. There is a distinction between urbanization and urbanism as a way of life. While urbanization includes a larger economic, social, cultural, political, and institutional transformation from rural to urban; urbanism as a way of life is a transformation on people's attitudes, behaviors, and life styles from rural type to urban one. In regards to urbanization, in Turkey many cities are good cases, however, for the urbanism as a way of life, the cities in Turkey as Konya has still having rural life styles, behaviors and attitudes far from being a case for urbanism.

\section{Historical Roots and Emergence of Cities}

Archelogical sites showed us that first urban settlements were established in Mesopotamia (B.C. 3500), Egypt (B.C. 3000), China and India (B.C. 2500) mainly near the big rivers such as Euphrates and Tigris, Nile, or Indus. The emergence of agriculture and irrigation of agriculture lands forced the people to settle down around the rivers in productive plates (Benevolo, 1995: 19). 
In Sumerian cities like Ur, Eridu, Umma, and Erek showed us there were some other occupations and jobs such as soldiers, craftsmen, traders and administrators. The property ownership was born by surrounding and owning agricultural lands and fields, and with the surplus production, a group of people became responsible to protect the land and there were soldiers and were paid by the taxes given by land owners. Life became much more complex and for the complex needs of the people the other occupations were born such as tailors, blacksmith, pottery makers and some others. The social organization of the society and the administration of the people gave birth to the first city-states and than larger state organizations (Childe, 1995: 88)

Other than rivers, and productive agriculture lands, there are some several reasons carried by scientists to explain the emergence of the first cities. For instance, military explanation states that first cities were established for the self defense aim of the people around big castles. When the attack starts the people enter the castle and close the doors of the castles. Therefore, there are many cities called as ...burgh in Europe. Secondly, religion sometimes played a key role for the establishment of the first cities. Some first cities like in Ancient Greece, were established around a big temple. Instead of carrying the Gods, people constructed huge sculpts of Gods and built up big temples. They settled around the temples to sacrifice and pray regularly for the Gods. Thirdly, like in ancient Anatolia, some first cities were constructed around big bazaars as trade centers on the main trade roads (Bal, 2008: 42-43). As it can be seen that there is not only one concrete explanation to explain the establishment of the first city settlements in history. However, the most important point is urban is crucial to understand humanity not only just after the Industrial Revolution, but even in the B.C period of history.

\section{Classical Sociological Theories on Urban}

There are some classical theories to define urban and to order the common features of urban settlements. F. Tönnies divides rural and urban as gemeinschaft" and "gesellschaft" that means community and society, similar to Durkheim's organic and mechanic solidarity distinction. Gemeinschaft or mechanic solidarity refers to rural type of society in which there is closed and face to face relations, a sense of being "us", dominance of traditions, superstitions, religion, agriculture or husbandry, labor intensive production, lower technology, and lower occupational specialization (Durkheim, 1964 and Tönnies, 1988). Simmel, adds some another features for cities. In urban area, rational behaviors, individual profits, market economy, money movements, and much more complex economic life is dominant (Simmel, 1996: 81-89).

Another classical thought in sociology is Marxism and based on property ownership and production relations. Marxist understanding tries to analyze capitalism and capitalism was firstly organized in cities. The cities of industrial production and free market economy were born with capitalism together. The rise of European cities after the dissolution of feudal system is the main skeleton of the Marxist theory on capitalism. The class structure in capitalist system, the bourgeois and the working class, is also city based social structure. The relations and the struggle between those two classes occur in urban; so urban has crucial place in Marxist theory (Marx \& Engels, 1999: 82-341).

Another main scholar in Sociology is Weber, and he draws a city typology. Instead of giving one definition, he mentions about the urban history of Western civilization and tells about some urban types. There are production and consumption cities. While production cities are specialized on economic activities and production, consumptions cities are generally capital cities and centers for bureaucracy, and take the surplus value of the production cities as tax. There are also garrison and military towns that consume rather than produce (Sezal, 1992: 31).

As it is seen that classical Sociologists were dealing with emergence and definition of cities, and brought different points of views on urban. Around those different definitions and points of views, we can find out some common features and definitions of cities. For example, cities are hosting different social groups, including different ethnic groups, different classes, different socio-economic groups, different cultures or sects. Secondly, in cities population is bigger and population density is higher relatively than rural areas. Thirdly, among the people there is a social distance, individualism is higher, and there is a sense of "me" rather than "us". Cities bring more independence. Rather than traditions and informal relations, there are formal relations and professionalism. Labor is organized and working is based on specialized division of labor and professional occupations are common. Mobility based geography and mobility among social groups and classes are possible and common. Transportation, communication and other physical infrastructure facilities are developed. Te culture is dynamic in cities and art and culture facilities are well developed. Cultural change is rapid and scientific activities are improved. There are much more economic opportunities, education, and health facilities. On the other hand, lastly, crime, drug addiction, traffic accidents, and disorder are common in cities (Yörükan, 1968: 19-26). 


\section{Chicago School and Modernization Perspective on Urban}

After the World War I. and the World War II. the cities got bigger and urbanization process became faster. The new era of the humanity was called as modernization. Especially, the US hegemony became dominant in the world and American type of modernization and westernization became the main development road for the countries. Urbanization and modernization went through together and many times urbanization and modernization processes became two different faces of one coin. Since urbanization overlaps modernization, the definition or urbanization is equal to the definition of modernization. From rural to urban society, from agriculture to industry and service sector, from labor intensive to technology intensive, from community to society, urbanization and modernization is a linear and western way of development.

In Chicago School, there are famous figures on urban studies, Robert Park, Ernest Burgess, and Louis Wirth. Park and Burgess represent human ecological perspective. "The City" written by park and Burgess (1925) is the main systematic urban theory of the Chicago Schol. They apply ecological understanding on the development of urban areas. From the center to the outskirts, cities are getting wider and wider as rings. They try to understand the geographical enlargement of cities, and they state that in the center ring, there are business and trade centers. Around the central business center, the second ring is being fulfilled by the lower class people, criminals, working class, lower quality buildings and cheaper apartments. The third ring is the neighborhoods of middle class. Then later suburb rings take place. The way getting enlarges, and the taking place of economic facilities, social groups according to those rings is the main subjects of Chicago School. They try to estimate the future development of any city through this way and raise policies accordingly (Giddens, 1993: 98-99).

\section{Urbanism as a Way of Life}

Rather than enlargement of cities on space and development process through time, or instead of economic, ecological or geographical improvement of cities, Louis Wirth focuses on the social behavior as an outcome of urbanization. Urbanization effects on human behavior and there are unique behaviors that urban people act. Urban people differ from rural people in terms of acts, attitudes, and behaviors. Wirth distinguishes rural and urban in regards to life style, and urbanization, for Wirth, is also a transformation of lifestyle (Wirth, 1938: 112-116). The social dimension of urbanization based on human behavior is the subject of this article. In Turkey, urbanization occurs in terms of geographical enlargement, rise of population density, or improvement of physical conditions. However, in terms of human behaviors, social scientists wait for unique urban behaviors from the living people to define that city as urban.

On the base of Wirth's view, mass culture shapes human life, face to face relations, and informal ties such as relative relations or neighboring decreases. With higher individualism and professionalism, rational decision taking, rational behaviors based on profit calculation, dominates urban life. Money based economy and trade relations and some other main rules of capitalism dominate urban economics. Each part of urban has different characteristics, so there many type of people living in urban. The heterogeneous social structure brings respect for differences, tension of democracy and freedom. Other than government there are many non governmental institutions and organizations participate into urban life (Wirth, 1938: 123-125). Urban people believes in science and the domination of religion decreases, urban people gives importance to arts and esthetics, uses time consciously, uses technology and follows technological improvements. Politically, an urban person is interested in politics and joins political organizations, and votes as citizenship right. An urban person is aware of being citizen and takes role in NGO structures. An urban person believes in gender emancipation, gives importance to education, and democratic values. The family structure is nucleus family and not father centered in decision making process (Bal, 2008: 81).

Theoretically, Wirth is right and we expect those social behaviors and attitudes from an urban person. However, in practice, in urban areas, relative relations are still strong, religion is still dominant and urban Islam is being studied by many scholars as the togetherness of Islam and city life. Irrational behaviors, conservatism, traditions, can be seen in cities today easily. Woman participation into economic life is still limited in urban areas. All those figures show us that urbanization is not following the same way as Wirth mentions in terms of human behavior. In addition, closed relations and friendships are still continuing, and an urban person is not so alone or individualist as Wirth thinks (Giddens, 2000: 507).

The biggest critique against Wirth is brought by Gans. He mentions that Wirth's theoretical assumptions cannot be valid or applicable for all cities in the World. There are many outskirt neighborhoods or slums in cities in where rural attitudes or behaviors are still maintaining Gans, 1962). Some rural structures or institutions, such as fellow countryman 
solidarity (hemşehri in Turkish), are still surviving in urban areas of Turkey. In addition, family based apartments and suburban settlements are newly emerged and popular areas in cities of Turkey. For Gains, Wirth's assumptions are true for the upper class people living in the inner city but not valid for the people living in slum or suburbs.

\section{Urbanization and Migration in Turkey}

Compared to western cases, the cities in Turkey are relatively newly emerged and except some several historical cities like İstanbul, İzmir, Konya, many cities are shorter urban history. The enlargement of cities in Turkey is based on migration from rural area. The first migration wave was after 1950s, the second was after 1980s; therefore urban people in Turkey have rural connections and carrying on rural characteristics today. Since the biggest reason is that the migration was not old and the people in cities are still keeping their relations with their rural roots, the cities in Turkey are still being labeled as urban villages.

Before defining the cities in Turkey as urban village, we must understand the migration history of Turkey from rural to urban. The migration from rural to urban has the highest speed after 1950 that can be called first wave. The mechanization of agriculture and the division of lands among the sons as the heritage of father created unemployment in rural area. The job opportunities in urban areas became the main attractive feature of the cities for rural people in Turkey. The migrated people established closed connections with the other migrated people from their own hometown and the hemşehri relations became a balanced instrument to make them adopt to the city life easily (Peker, 1999: 298). The migration brought the shanty town (gecekondu) phenomenon in Turkey. However, Turkish experience of shantytown is different than the Latin American way of shantytown, therefore the term of gecekondu is typical for Turkish case. In 1970s, Turkey was the second country after Columbia, in terms of the share of shantytown houses in cities. In Ankara, the proportion of gecekondu was $60 \%$ and in İzmir it was 65 \% (Karpat, 2003: 36-37). In the first wave of migration, the migrated people illegally occupied the public lands and construct their houses with the help of the other people from their hometowns. The user and maker of the house was the same and they constructed their houses to live in it. After constructed their houses, they adopted themselves to the urban and they used the facilities of the cities. However, the gecekondu construction took other parameters after 1970s. Some companies were born to construct gecekondu, and other than living in it, gecekondu blocks were constructed to rent. In the outskirts of the cities the lands were occupied and sold to the people who want to construct gecekondu. The new type of gecekondu is an apartment flat type and not connected to the city life. They created new suburb areas (Bal, 2008: 119).

The improved education and health facilities, job opportunities pushed the rural people to urban areas. However, after 1980s, the terrorism in East part of Turkey created a new wave of migration. The new type of migration brought a deeper poverty and crime to the city areas. Rittersberger divides the migration ways as rational-individual, and mass migration. The second wave of migration after 1980s was the mass and forced migration from the Eastern villages to western cities (Rittersberger, 2000). There is also seasonal migration from Eastern and poor parts of the country to the richer agricultural areas of Çukurova and Black sea region for cotton or hazelnut collection (Özcan, 1998: 83).

The waves of migration show that the cities in Turkey, including the oldest centers of civilizations, have the rural characteristics in their some part as the result of migrated rural people. Therefore, it can be easily claimed that although there is a rapid urbanization in Turkey, urbanism as a way of life is not improved enough. This study will focus on Konya to test whether there is urbanism or not, based on the surveys held by the Metropolitan Municipality.

\section{The Methodology}

The indicators of the study about Konya are based on the research conducted by the Konya Metropolitan Municipality. The first research is about the lifestyle in Konya. The research was conducted between 15 November and 31 December 2004. In the metropolitan area, totally 2600 persons were selected through simple random sampling. The second research is about urban culture and urbanism consciousness in Konya, conducted between 8 November and 20 December 2004, applied questionnaire on 2682 person selected by simple random sampling in the metropolitan area. The third research was on neighboring behavior of Konya. The research was applied between 21 October and 30 November 2004 on 2579 persons. The face to face questionnaires applied the samples which were selected through simple random sampling in the metropolitan area.

In this study, not all the questionnaire results, but the relevant ones were used to analyze the urbanism as a way of life in Konya. 


\section{Some Results}

In each research, the results were published by the Municipality and they label their won cities as the city of religion and tradition. The conservatism and religiousness are the typical characteristics of Konya. While in urban areas, social scientists expect the decline of religion and traditions in people's life. Urbanism as a way life refers to an urban person whose life is not dominated by religion and traditions.

If we consider about the results of the religiousness of the people living in the metropolitan area of Konya, there are some questionnaire results. For example; their attitudes towards praying is religious in Konya. $98.6 \%$ of the participants said that they fast in Ramadan regularly. $82.4 \%$ of the participants go to Friday pray regularly (Kent Araştırmaları 2, 2006: 103).
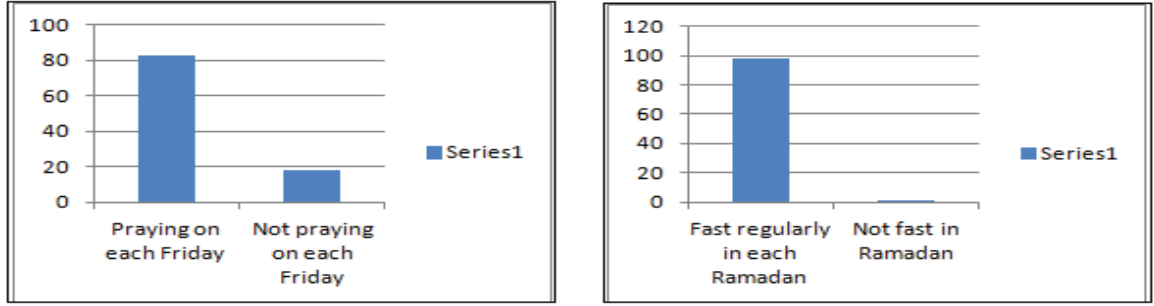

$10 \%$ of the participants believe the power of religious persons (hacı-hoca) to find solution their illnesses (Kent Araştırmaları 2, 2006: 107). $21.7 \%$ of the participants watch religious programs on TV channels mostly (Kent Araştırmaları 2, 2006: 120). Among the participants, only $6.7 \%$ of them consume alcohol, $93 \%$ said they never take alcohol (Kent Araştırmaları 2, 2006: 138).

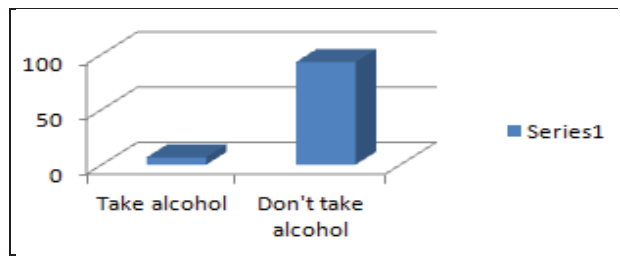

If we look at the participants' definition of lifestyle, 38,7 5 of the participants defined obeying traditions, 13,6\% defined obeying belief and religion, 13,4 \% defined obeying what you saw from your ancestors (Kent Araştırmaları 2, 2006: 177). In regards to political view, $22,9 \%$ is conservative, $21,6 \%$ is Islamist, 20,2 is religious, 19,7 is nationalist, $7,7 \%$ is secular, 6,8 \% is democrat, 2,1 is social democrat (Kent Araşıırmaları 2, 2006: 185).

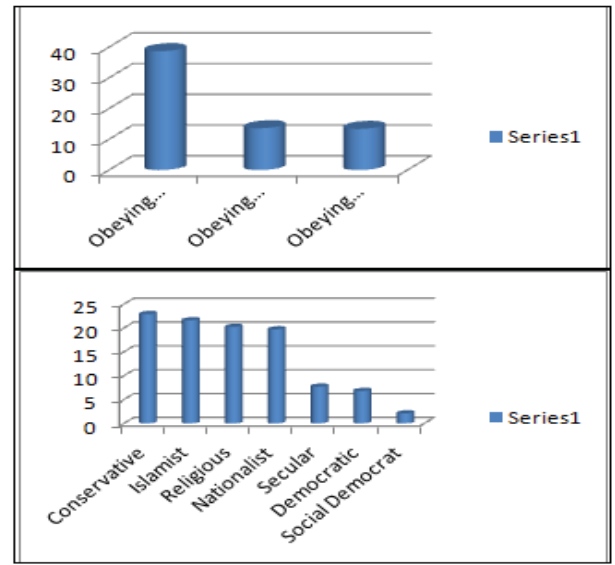


$51,6 \%$ of the participants said that Turkey must not be closed to Western culture, on the other hand, 28,1\% accepted that Turkey must be closed to Western culture (Kent Araştırmaları 2, 2006: 188). 83,7 \% of the participants see traditions the most important value than everything, but only $7 \%$ said the opposite (Kent Araştırmaları 2, 2006: 190). 56,6\% of the participants claim that decisions must be taken by men at home, and only $29,5 \%$ claimed that decisions must be taken equally both men and women at home (Kent Araştırmaları 2, 2006:194).
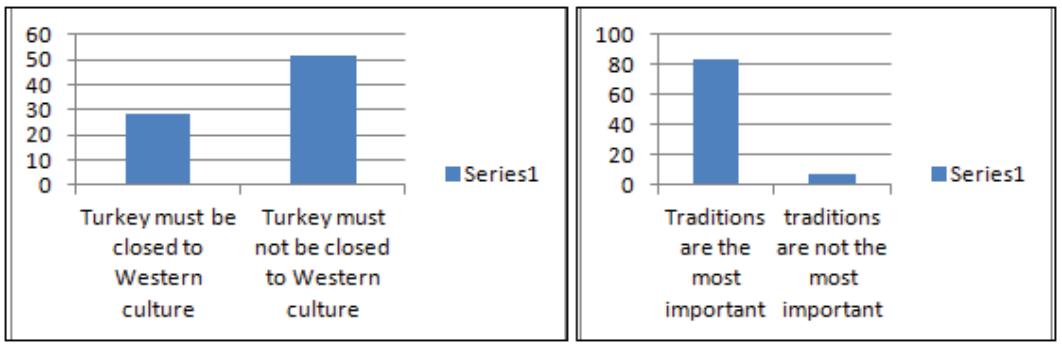

When the local people of Konya describes their own cities to foreigners, firstly they mention that Konya is the most religious city in Turkey with 18,8\%. After Mevlana, being religiousness is the second trade mark of Konya (Kent Araştırmaları 3, 2006: 70-74). The questionnaire asked to the people that which foreign city they visited. Mecca and Medina are the main cities that the people in Konya visited. Mecca with $30,4 \%$ is the first city, Medina with 19,1 second city. The people living in Konya want to see Germany first and than secondly Saudi Arabia. There are many relatives living in Germany, as migrated Turks, therefore they may answered Germany as the first country, but the second country Saudi Arabia has been chosen for religious reasons (Kent Araştırmaları 3, 2006: 79 and 89). In the research, the participants were asked about the origin of the name of the city Konya. Only 1,2\% said that the name comes from ancient Greeks, and 3,8 \% said that it comes from Iconium (the Christian icons). Totally, $5 \%$ gave the true answer. However all the other participants gave the Islamic and religious myths of Konya, such land on (kon) of two angels or Mevlana (Kent Araştırmaları 3, 2006: 83). The membership of NGO is very unique indicator for urbanism as a way of life, however in Konya, the participants are the members of mosque construction foundations with $10.2 \%$ (Kent Araştırmaları 3, 2006: 96).

The other important indicator is the usage of public sphere. The urban life is unique with its developed public spheres and respect for the public spheres. The local people in Konya do not own the public sphere. In the questionnaire, $87 \%$ of the people has seen persons who spit out, $83,8 \%$ has seen persons who throw garbage away, 89,5\% has seen persons who throw cigarette ends on the floor in the public sphere. 59,9\% of the participants has seen persons who damaged the publicly used instruments like buses, parks, or tram. (Kent Araştırmaları 3, 2006: 107,109,111, 112).

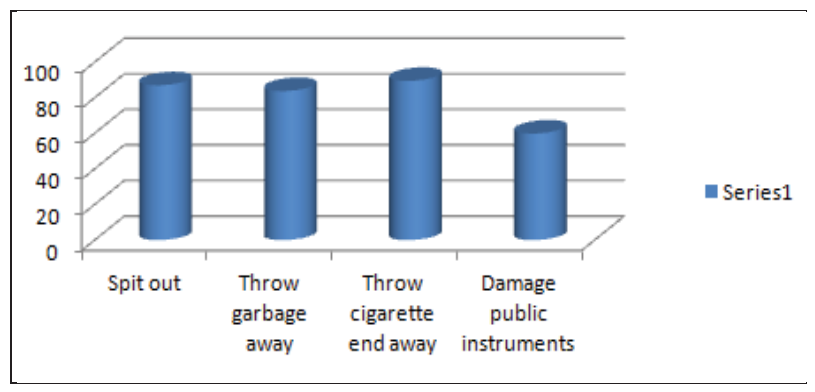

The third research was about the neighboring habits of the living people in Konya. For the 92,3 of the participants, neighbors must be religious, for the 99,6, neighbor must be ethical, for the 99,2, neighbor must respect for privacy. 


\section{Conclusion}

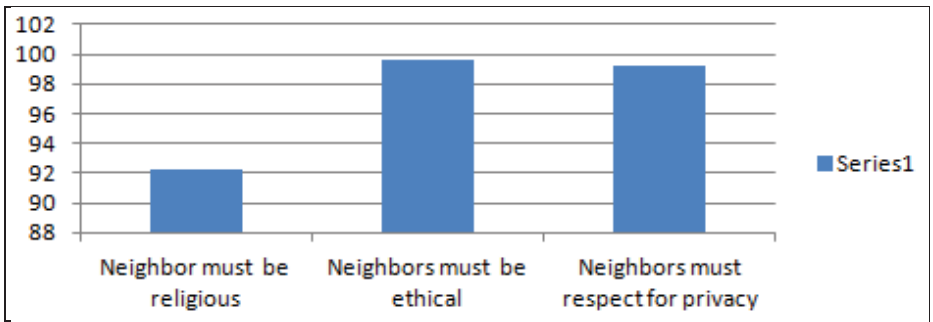

As the results show us that although Konya is well developed city in turkey in regards to shopping centers, improved infrastructure facilities, with 4 universities, hospitals, schools, population density; Konya is known as the city of conservatism and religiousness. The indicators showed us that the living people in Konya give importance traditions and customs; and religion plays a crucial role in their social life. The classical modernist understanding can sign those attitudes and behaviors as rural values, but in Konya, one of the biggest metropolitan cities in Turkey, can be seen conservatism and religiousness than any other small city or rural area. It shows that conservatism and religion can reproduce in urban and can be dominant in city. Not like in Western cases, but in non-Western cases, rural attitudes and characteristics can be part of urban life eclectically. Western origin theories cannot explain the non-Western cases truly and there can be different ways of urbanization or modernization different from Western experiences. Konya is the best case as a city with its open market economy, doing export and accumulated to the global capitalist system but religious and conservative at the same time.

\section{References}

Bal, H., Kent Sosyolojisi, Isparta: Fakülte Yayınevi, 2008.

Benevolo, L., Avrupa Tarihinde Kentler, çev. Nur Nirven, İstanbul: Afa Yayınları, 1995.

Childe, G., Tarihte Neler Oldu çev. Mete Tunçay ve Alaeddin Şenel, İstanbul: Mihrican Yayınevi, 1995.

Durkheim, E., The Division of Labor, trans. by George Simpson, London: Free Press, 1964.

Gans, H.J., "Urbanism and Suburbanism as a Way of Life" in A.M. Rose ed. Human Behavior and Social Processes, pp: 625-648, Boston: Houghton Mifflin, 1962.

Giddens, A., Sosyoloji: Eleştirel Bir Yaklaşım, çev. R. Esengün, İ. Öğretir, İstanbul: İtar Yayıncılık, 1993.

Giddens, A., Sosyoloji, çev. H. Özel \& C. Güzel, İstanbul: Ayraç Yayınları, 2000.

Karpat, K., Türkiye'de Toplumsal Dönüşüm: Kırsal Göç, Gecekondu ve Kentleşme, çev. Abdulkerim Sönmez, Ankara: İmge Yayınları, 2003.

Kent Araşıırmaları 2, Konya'da Hayat Tarzı, Konya: Konya Büyükşehir Belediyesi, 2006.

Kent Araşsırmaları 3, Konya'da Kent Kültürü ve Kentililik Bilinci, Konya: Konya Büyükşehir Belediyesi, 2006.

Kent Araşıırmaları 4, Konya'da Komşuluk Araştırması, Konya: Konya Büyükşehir Belediyesi, 2006.

Marx, K. \& Engels, F., Alman Ideolojisi, çev. S. Belli. Ankara: Sol Yayınları, 1999.

Özcan, Y.Z., İçöçün tanımı ve Verileri ile illgili Bazı Sorunlar, İstanbul: Tarih Vakfı Yayınları, 1998.

Peker, M., "Türkiye'de İçgöçün Değişen Yapısı", 75.Yılda Köylerden Şehirlere, İstanbul: T. İ̧̧ Bankası Yayınları, 1999.

Rittersberger, H., "Türkiye'de içgöç ve Toplumsal Değişme", Karizma Dergisi, Sayı: 6, Yıl: 2. (2000).

Sezal, İ. 1992, Şehirleşme, İstanbul: Ağaç Yayınları.

Simmel, G. 1996, "Metropol ve Zihinsel Yaşam" çev. B.Ö. Düzgören, Cogito, no: 8, İstanbul, ss: 81-89, (Yaz-1996).

Tolan, B., Toplumbilime Giriş, Ankara: Adam Yayınları, 1991.

Tönnies, F., Community and Society, trans. by Charles P. Loomis, Oxford: Transaction Books, 1988.

Wirth, L., Urbanism as a Way of Life, in P. Hatt and A.J. reis eds. Cities and Society, New York: Free Press, 1938.

Yörükan, A., Sehir Sosyolojisinin Teorik Temelleri, Ankara: İmar ve İskan Bakanlığı, 1968.

http://www.tuik.gov.tr/PreHaberBultenleri.do?id=10736, last modified, August 18, 2012. 